\title{
FISHERY IN THE TRIBUTARIES OF YAMUNA RIVER (KEN RIVER, PAISUNIRIVER) AND GANGA RIVER (TONS RIVER)
}

\author{
Prakash Nautiyal $^{1}$ and Amitabh Chandra Dwivedi ${ }^{2}$ \\ ${ }^{1}$ Department of Zoology and Biotechnology, H.N.B. Garhwal University (A Central University), Srinagar \\ 246174, Uttarakhand, India. \\ ${ }^{2}$ Department of Zoology, Nehru Gram Bharati (Deemed to be University), Prayagraj, Uttar Pradesh
}

Corresponding Author E-mail id: pn.mahseer@gmail.com

Received: 23.09.2019; Revised: 15.10.2019; Accepted: 22.11.2019

(C)Society for Himalayan Action Research and Development

\begin{abstract}
A study on the landings of various species recorded randomly from December 2003 to June 2004 from fish landing and marketing centers on the Ken at Banda, on the Paisuni at Karwi and Tons at Chakghat and Sadiapur (Prayagraj), revealed that the average catch day ${ }^{-1}$ of the Ken river was dominated by Cyprinus carpio followed by Aorichthys spp. and miscellaneous fish. In contrast the Paisuni R. was dominated by Labeo calbasu followed by Hypophthalmichthys molitrix and miscellaneous while the latter group dominated over Aorichthys spp and $L$. calbasu in the Tons R. Among selected species Labeo rohita commands higher price (Rs 61.7), Tor tor moderate (Rs 52.5) and L. calbasu lower price (Rs 37.5).
\end{abstract}

Keywords: Fishery, Rivers, Ken, Paisuni, Tons

\section{Introduction}

Freshwater fishes are vital and valued property for income, human food security, sport and ornaments. Overexploitation occurs around the world with the operation of more and more refined fishing equipment. Shrinkage of many wild fish stocks has been documented as a result of expanding fisheries (Allan et al 2005, Dwivedi and Nautiyal 2012, Pinder et al 2019). Illegal fishing using dynamite, pesticides, electrofishing, etc. are also major threats to fish stocks all over the world (Nautiyal et al 2013). Fishery resources are an economic activity (Dwivedi and Nautiyal 2010). In the Ganga basin, first instance of organized fishery happens at Prayagraj and at subsequent major cities of Uttar Pradesh, Bihar and West Bengal. The commercially important fishes are ritually categorised into major carps (high culinary preference), other important carps comprising indigenous and exotic carps, important catfishes such as bagarids, siluroids and other such as murrels, feather backs and eel. A survey was conducted during 2003-2004 to know the catch structure and price of selected major - minor carps (Labeao rohita, Labeao. calbasu, Tor tor) and catfish in the fish markets to know how changes in catch composition have modified or influenced the pricing patterns and thus put pressure on the concerned fish species.

\section{Study area}

The fishery samples were obtained from fishermen or from fish market at Banda in case of the Ken R. and Karwi in case of the Paisuni R. Additional information was obtained for L. rohita, L. calbasu and T. tor. Experimental fishing was also performed for obtaining the samples of $T$.tor from Chitrakoot Dham (Paisuni river). In case of the Tons R. fish samples were obtained from fish market at Sadiapur/Gaughat, Prayagrajas there was no local market at Chakghat where fishery related observations were made. The fishermen sell their catch at Sadiapur/Gaughat, Allahabad. The species price was recorded throughout the sampling period from the vendors on sampling days. For the sake of convenience they were 
categorised as follows $<0.5 \mathrm{Kg},<1.0 \mathrm{Kg},<1.5 \mathrm{Kg}$, $<2.0 \mathrm{Kg},<3.0 \mathrm{Kg}$, and $<4.0 \mathrm{Kg}$ and price was recorded for all fishes in these major categories. This helped in determining the price range and descriptive analysis were computed using MS Excel software

\section{Methods}

\section{Catch Structure: Catch per day and its composition}

The initial part of the study was to know the quantum of the catch and its composition to select suitable fishes for the study. Catch is a crude indicator of population size. Catch day ${ }^{-1}$ gives an estimate of the quantum of fish catch and its components. Catch composition provides a breakup of the landings and quantum contribution of different species to this commercial activity. Change in the relative numbers of the different species is one measure of the abundance for the total populations of all species in a water body.

Catch day ${ }^{-1}$ : Several types of collection systems are in use for the total catch (by numbers or weight). The chief types of collection system are the annual canvass, the sales slip, vessel landing, $\log$ books, daily delivery sheets, fixed gear records and sport fish records. A measure of fishing effort should satisfy various requirements. Important among them the effort should be a time and/or gear unit used by the fishermen or dealer in transacting business. If the dealer buys each day's catch from the fishermen, then a day may be a convenient unit of time (Rounseefell and Everhart 1985).

In order to obtain catch day ${ }^{-1}$, quantity of each fish species sold on that particular day by the vendors was obtained by weighing all fishes of one species. This was repeated for all vendors present on that particular day. Thus, the quantity of fishes from each vendor was added so as to obtain an estimate of the total catch on one day, hence forth termed as Catch day ${ }^{-1}$. A monthly value (mean, SE, median and others) was obtained by computing descriptive statistics (MS Excel 5.0) from the catch day ${ }^{-1}$ recorded during the number of sampling days in the particular month.

\section{Results and discussion}

Fisheries sector plays an important role in Indian economy by contributing to national income, exports, food, nutritional security and employment generation (Salim and Halawai 2005, Dwivedi and Nautiyal 2010). Marketing channels play a vital role in meeting the demand for fish (Masud 2004). Fish landings are conveniently categorized as commercially important fish species of large size which regularly form bulk of the catch and miscellaneous fishes which are regular but owing to their small size contribute very little to the total catch by weight.

Commercially important fish i. e. the species, which are in great demand in fish markets owing to their quality of flesh or due to demand generated by market forces, were divided into; major carps - Labeo rohita (Hamilton), Catla catla (Hamilton), Cirrhinus mrigala (Bloch) and Labeo calbasu (Hamilton), other carp- Tor tor, (Hamilton), exotic carps Ctenopharyngodon idella, (Valenciennes), Cyprinus carpio Linnaeus and Hypophthalmichthys molitrix (Valenciennes), important catfishes-Aorichthys aor (Hamilton), A. seenghala (Sykes), Rita rita (Hamilton) and Wallago attu (Bloch \& Schneider), other important fishes- Channa punctatus (Bloch), C. marulius (Hamilton), C. striatus (Bloch), Chitala chitala (Hamilton), Notopterus notopterus (Pallas), Mastacembelus armatus (Lacepede) and miscellaneous. $T$. tor was given a specific category as it constitutes back bone of the fishery in the Narmada river and over years there has been a general decline in its abundance (Table 1). However, not much is known about them in the tributaries of the Yamuna and Ganga, which flow northward, compared to west flowing Narmada.

\section{Catch and its Structure}

The Ken River: The total catch was dominated by C.carpio ( 9.36 to $24.95 \mathrm{Kg} \mathrm{day}^{-1}$ ), Aorichthys spp (11.35 to $15.8 \mathrm{Kg} \mathrm{day}^{-1}$ ) and miscellaneous group (9.88 to $12.55 \mathrm{Kg} \mathrm{day}^{-1}$ ) as they accounted for 12.4 to $22.4 \%, 9.69$ to $21 \%$ and 10.7 to $13.1 \%$, respectively (Table 2 ). 
In the Ken river the monthly average catch of $L$. calbasu amounted for 7.07 to $14.15 \mathrm{Kg} \mathrm{day}^{-1}, L$. rohita 3.1 to $13.5 \mathrm{Kg} \mathrm{day}^{-1}$ and T. tor 0.67 to 4.3 $\mathrm{Kg}$ day $^{-1}$. Among these three species $L$. calbasu and $L$. rohita were dominant component of the catch accounting for 8.44 to $12.2 \%$ and 4.4 to $11.5 \%$ while $T$. tor share was low ranging from
0.8 to $3.67 \%$ (Table 2). The average obtained by pooling catch figures for the period of observation (Table 3, Fig. 1) were high for L. calbasu (11.0\%), followed by $L$. rohita $(6.21 \%)$ and $T$. tor $(2.82 \%)$, suggesting the larger share of L. calbasu in the catch.

Table 1 Commercial and miscellaneous component of the fish landings in the rivers of the Bundelkhand region-Ken, Paisuni and Tons rivers at Banda, Karwi and Sadiapur fish markets

\begin{tabular}{|c|c|}
\hline Commercial component & Miscellaneous component \\
\hline Major carps & Minor carps \\
\hline Catla catla (Hamilton) & Labeo boggut $\quad$ (Sykes) \\
\hline Labeo calbasu (Hamilton) & L. fimbriatus \\
\hline Labeo rohita (Hamilton) & (Hamilton) \\
\hline Cirrhinus mrigala (Bloch) & L. dyocheilus \\
\hline Other carps & L. gonius (Hamilton) \\
\hline Tor tor $\quad$ (Hamilton) & Cirrhinus reba (Hamilton) \\
\hline Exotic carps & Puntius ticto(Hamilton) \\
\hline Ctenopharyngodon idella (Valenciennes) & P. sophore (Hamilton) \\
\hline Cyprinus carpio Linnaeus & P. chola (Hamilton) \\
\hline Hypophthalmichthys molitrix (Val.) & P. conchonius \\
\hline Important catfishes & Barilius bola (Hamilton) \\
\hline Aorichthys aor (Hamilton) & Osteobrama cotio cotio (Hamilton) \\
\hline Aorichthys seenghala (Sykes) & Aspidoparia morar (Hamilton) \\
\hline Rita rita (Hamilton) & Catfishes \\
\hline Wallago attu (Bloch \& Schneider) & Mystus vittatus \\
\hline Other important fishes & (Hamilton) \\
\hline Channa punctatus (Bloch) & M. cavasius \\
\hline Channa marulius (Hamilton) & M. bleekeri \\
\hline Channa striatus (Bloch) & Clarius batrachus (Linnaeus) \\
\hline Chitala chitala (Hamilton) & Bagarius bagarius(Hamilton) \\
\hline Notopterus notopterus (Pallas) & Clupisoma garua (Hamilton) \\
\hline \multirow[t]{11}{*}{ Mastacembelus armatus (Lacepede) } & Ailia coila (Hamilton) \\
\hline & $\begin{array}{ll}\text { Siloniasilondia } & \text { (Sykes) } \\
\end{array}$ \\
\hline & Pangasius pangasius \\
\hline & Gagata cenio \\
\hline & Others/Perch \\
\hline & Chanda nama \\
\hline & Parambassis ranga(Hamilton) \\
\hline & Setipinna phasa (Hamilton) \\
\hline & Goniolosa manmina (Hamilton) \\
\hline & Colisa fasciata $\quad$ (Schneider) \\
\hline & Anabas testudineus (Bloch) \\
\hline
\end{tabular}


Table 2. Monthly catch $\left(\mathrm{Kg}\right.$. day $\left.{ }^{-1}\right)$ of important species in the river Ken.

\begin{tabular}{|l|l|l|l|l|l|l|}
\hline Species & \multicolumn{2}{|l|}{ December } & April & \multicolumn{2}{l|}{ June } \\
\hline & Kg. & $\%$ & Kg. & $\%$ & Kg. & $\%$ \\
& & & & & & \\
\hline Labeo rohita & 3.68 & 4.4 & 13.5 & 11.5 & 3.1 & 4.11 \\
\hline Catla catla & 2.27 & 2.71 & 5.4 & 4.61 & 1.3 & 1.73 \\
\hline Cirrhinus mrigala & 6.43 & 7.68 & 12.55 & 10.7 & 1.76 & 2.34 \\
\hline Labeo calbasu & 7.07 & 8.44 & 14.15 & 12.1 & 9.17 & 12.2 \\
\hline Tor tor & 0.67 & 0.8 & 4.3 & 3.67 & 2.75 & 3.65 \\
\hline Cyprinus carpio & 18.8 & 22.4 & 24.95 & 21.3 & 9.36 & 12.4 \\
\hline Ctenopharyngodon idella & 1.83 & 2.19 & 1.8 & 1.54 & 3.28 & 4.35 \\
\hline Hypophthalmichthys molitrix & 0 & 0 & 0 & 0 & 0 & 0 \\
\hline Aorichthys spp. & 15.2 & 18.1 & 11.35 & 9.69 & 15.8 & 21 \\
\hline Wallago attu & 7.87 & 9.39 & 7.2 & 6.15 & 7.4 & 9.82 \\
\hline Rita rita & 0.46 & 0.55 & 2.2 & 1.88 & 5.14 & 6.82 \\
\hline Channa spp. & 3.25 & 3.88 & 0.85 & 0.73 & 1.12 & 1.49 \\
\hline $\begin{array}{l}\text { Notopterus } \text { notopterus } \text { and } \text { Chitala } \\
\text { chitala }\end{array}$ & 5.47 & 6.53 & 2.85 & 2.43 & 2.86 & 3.8 \\
\hline Mastacembelus armatus & 0 & 0 & 3.45 & 2.95 & 2.42 & 3.21 \\
\hline Miscellaneous & 10.8 & 12.9 & 12.55 & 10.7 & 9.88 & 13.1 \\
\hline
\end{tabular}

Table 3. Variations in the average catch $\left(\mathrm{Kg}\right.$ day $\left.^{-1}\right)$ of important species in the rivers Ken, Paisuni and Tons at Banda, Karwi and Sadiapur, respectively.

\begin{tabular}{|l|l|l|l|l|l|l|}
\hline Species & \multicolumn{2}{|l|}{ Ken } & Paisuni & \multicolumn{2}{l|}{ Tons } \\
\hline & Kg. & $\%$ & Kg. & $\%$ & Kg. & $\%$ \\
\hline Labeo rohita & 5.36 & 6.21 & 2.22 & 4.88 & 2.69 & 8.3 \\
\hline Catla catla & 2.41 & 2.8 & 1.86 & 4.1 & 1.41 & 4.35 \\
\hline Cirrhinus mrigala & 5.32 & 6.17 & 2.96 & 6.5 & 2.51 & 7.75 \\
\hline Labeo calbasu & 9.54 & 11.0 & 6.72 & 14.8 & 3.93 & 12.1 \\
\hline Tor tor & 2.44 & 2.82 & 0.58 & 1.27 & 1.86 & 5.75 \\
\hline Cyprinus carpio & 15.3 & 17.8 & 2.93 & 6.43 & 1.32 & 4.06 \\
\hline Ctenopharyngodon idella & 2.55 & 2.96 & 0 & 0 & 1.19 & 3.66 \\
\hline Hypophthalmichthys molitrix & 0 & 0 & 6.17 & 13.6 & 0.12 & 0.36 \\
\hline Aorichthys spp. & 14.7 & 17.1 & 3.89 & 8.53 & 4.64 & 14.3 \\
\hline Wallago attu & 7.5 & 8.7 & 2.67 & 5.86 & 2.34 & 7.22 \\
\hline Rita rita & 3.15 & 3.65 & 1.32 & 2.91 & 2.02 & 6.21 \\
\hline Channa spp. & 1.71 & 1.98 & 0.77 & 1.69 & 0.98 & 3.03 \\
\hline $\begin{array}{l}\text { Notopterus } \\
\text { Chitala chitala }\end{array}$ & 3.64 & 4.22 & 3.94 & 8.64 & 2.05 & 6.33 \\
\hline Mastacembelus armatus & 1.9 & 2.2 & 2.51 & 5.52 & 0.5 & 1.54 \\
\hline Miscellaneous & 10.7 & 12.4 & 5.58 & 12.3 & 4.87 & 15 \\
\hline
\end{tabular}

In terms of major groups of fishes, the major carps hence, accounted for 15.3 to $45.6 \mathrm{Kg} \mathrm{day}^{-1}$, the other carps 0.67 to $4.3 \mathrm{Kg} \mathrm{day}^{-1}$ and the exotic carps 12.6 to $26.8 \mathrm{Kg}$ day $^{-1}$. The important catfishes comprised 20.8 to $28.3 \mathrm{Kg}$ day $^{-1}$, other important fishes varied from 6.4 to $8.72 \mathrm{Kg}$ day $^{-1}$ and miscellaneous group accounted for 9.89 to $12.55 \mathrm{Kg} \mathrm{day}^{-1}$. The major carps therefore formed 20.3 to $38.9 \%$ of the catch compared with 0.8 to $3.67 \%$ of other carp and 16.8 to $24.6 \%$ of the exotic carps. Other important fishes varied from 6.11 to $10.4 \%$ and miscellaneous group 
constituted 10.7 to $13.1 \%$ (Table 4). However, the average catch for pooled data was slightly higher (29.4\%) for important catfishes group $(25.4 \mathrm{Kg}$ day $\left.^{-1}\right)$ compared with the major carps $(22.6 \mathrm{Kg}$ day $\left.^{-1}, 26.2 \%\right)$. The exotic carps $\left(17.9 \mathrm{Kg} \mathrm{day}^{-1}\right)$ formed a sizeable part $(20.7 \%)$ of the catch while other carps, $T$. tor only a small share $\left(2.44 \mathrm{Kg}\right.$ day $^{-}$ $1,2.82 \%)$. Other important and miscellaneous fishes accounted for $7.25 \mathrm{Kg} \mathrm{day}^{-1}$ and $10.7 \mathrm{Kg}$ day $^{-1}$ thus contributing only $8.4 \%$ and $12.4 \%$, respectively (Table 5, Fig. 2).

The Paisuni River: In the Paisuni R., the monthly average catch of $L$. calbasu varied from 3.64 to $10.4 \mathrm{Kg} \mathrm{day}^{-1}$, L. rohita 0.25 to $4.03 \mathrm{Kg}$ day $^{-1}$ and T. tor 0.38 to $1.15 \mathrm{Kg}$ day $^{-1}$. Thus, L. calbasu was a dominant component in the Paisuni R. accounting for 9.63 to $24.0 \%$ compared with $L$. rohita 0.65 to $10.7 \%$ and T. tor 0.99 to $1.83 \%$. Among other fish in the catch Aorichthys spp. ranged from 3.1 to $4.4 \mathrm{Kg} \mathrm{day}^{-1}$ and miscellaneous group 3.71 to $8.68 \mathrm{Kg} \mathrm{day}^{-1}$, thus forming 7.02 to $10.7 \%$ and 9.83 to $16.2 \%$, respectively of the total catch. C. carpio varied from 2.8 to $8.06 \%$ (Table 6). The average pooled catch was $6.72 \mathrm{Kg} \mathrm{day}^{-1}$ for L. calbasu (14.8\%), $2.22 \mathrm{Kg} \mathrm{day}^{-1}$ for L. rohita $(4.88 \%)$ and $0.58 \mathrm{Kg} \mathrm{day}^{-1}$ for T. tor

(1.27\%). Aorichthysspp. $\left(3.89 \mathrm{Kg} \mathrm{day}^{-1}\right)$ formed a sizeable part (8.53\%) of the total catch. C. carpio and miscellaneous group constituted $2.93 \mathrm{Kg} \mathrm{day}^{-1}$ and $5.58 \mathrm{Kg} \mathrm{day}^{-1}$ (Table 3), thus contributing only $6.43 \%$ and $12.3 \%$, respectively (Fig. 3).

The major carps, other carp and exotic carps amounting to 10.7 to $15.2 \mathrm{Kg}$ day $^{-1}, 0.38$ to 1.15 $\mathrm{Kg}$ day $^{-1}$ and 5.59 to $17.4 \mathrm{Kg}$ day $^{-1}$ constituted 22.5 to $40.2 \%, 0.99$ to $1.83 \%$ and 14.8 to $27.8 \%$, respectively, in the Paisuni R. Thus, carps were dominant component of the catch while the important catfishes comprised 6.51 to $11.5 \mathrm{Kg}$ day $^{-1}$. Other important fishes varied from 6.41 to $9.9 \mathrm{Kg} \mathrm{day}^{-1}$ and miscellaneous group accounted for 3.71 to $8.68 \mathrm{Kg}$ day $^{-1}$. Thus, major carps dominated the catch (22.5 to $40.2 \%$ ) while the important catfishes comprised 17.2 to $18.3 \%$ only. Other important fishes varied from 9.9 to $17.0 \%$ and miscellaneous group constituted 9.83 to $16.2 \%$ (Table 7 ). The average pooled catch was hence higher (31.2\%) for major carps $(13.8 \mathrm{Kg}$ day $\left.^{-1}\right)$ compared with the exotic carps $(9.11 \mathrm{Kg}$ day $\left.^{-1}, 20.6 \%\right)$. Important catfishes $\left(7.88 \mathrm{Kg} \mathrm{day}^{-1}\right)$ formed a sizeable part (17.9\%) of the catch while other carp $T$. tor only a small share $\left(0.58 \mathrm{Kg} \mathrm{day}^{-1}\right.$, $1.31 \%)$. Other important fishes and miscellaneous group varied from 7.22 and $5.88 \mathrm{Kg} \mathrm{day}^{-1}$ (Table 5), thus contributing only $16.4 \%$, and $12.3 \%$ (Fig. 4).

The Tons River: In the Tons R., monthly (average) catch of $L$. calbasu accounted for 1.0 to $6.67 \mathrm{Kg} \mathrm{day}^{-1}$, L. rohita 0.0 to $9.55 \mathrm{Kg} \mathrm{day}^{-1}$ and T. tor 0.0 to $9.0 \mathrm{Kg} \mathrm{day}^{-1}$. L. rohita and T. tor were not recorded in one and two months, respectively. Thus, L. calbasu was a dominant component in this river also amounting to 3.53 to $19.3 \%$ followed by L. rohita 0.0 to $20.7 \%$ and T. tor 0.0 to $28.1 \%$. Aorichthys spp. comprised 1.0 to 7.75 $\mathrm{Kg}$ day $^{-1}$ of the catch compared with $C$. carpio (0.45 to $\left.2.78 \mathrm{Kg} \mathrm{day}^{-1}\right)$ and miscellaneous group 1.23 to $14.0 \mathrm{Kg} \mathrm{day}^{-1}$ (Table 8) amounting to 3.53 to $22.1 \%, 0.23$ to $7.81 \%$ and 2.67 to $49.5 \%$, respectively.

Among the species under observation the average pooled catch was higher for L. calbasu $(3.93 \mathrm{Kg}$ day $\left.^{-1}, 12.1 \%\right)$ than L. rohita $\left(2.69 \mathrm{Kg} \mathrm{day}^{-1}, 8.3 \%\right)$ and T. tor $\left(1.86 \mathrm{Kg}\right.$ day $\left.^{-1}, 5.75 \%\right)$. Aorichthys spp.4.64 Kg day ${ }^{-1}$ formed a sizeable part (14.3\%) of the catch. C. carpio and miscellaneous group constituted $1.32 \mathrm{Kg}$ day $^{-1}$ and $4.87 \mathrm{Kg}$ day $^{-1}$ (Table 3 ), thus contributing $4.06 \%$ and $15 \%$, respectively (Fig. 5).

Major carps accounted for 9.38 to $52.9 \%$, other carp 0.0 to $28.1 \%$ and exotic carps 1.77 to $14.7 \%$ in the Tons R. Thus, the carps were a dominant component of the catch while the important catfishes comprised 11.4 to $45.4 \%$ only. Other important fishes varied from 0.0 to $8.48 \mathrm{Kg}_{\text {day }}{ }^{-1}$ and miscellaneous group 1.23 to $14.0 \mathrm{Kg}$ day $^{-1}$ (Table 9), thus accounting for 0.0 to $18.4 \%$ and 2.67 to $49.5 \%$, respectively. 
Table 4. Monthly variations in the catch $\left(\mathrm{Kg} \mathrm{day}^{-1}\right)$ of major fishery components from the river Ken.

\begin{tabular}{|l|l|l|l|l|l|l|}
\hline Categories & \multicolumn{2}{|l|}{ December } & April & \multicolumn{2}{l|}{ June } \\
\hline & Kg. & $\%$ & Kg. & $\%$ & Kg. & $\%$ \\
\hline Major carps & 19.5 & 23.2 & 45.6 & 38.9 & 15.3 & 20.3 \\
\hline Other carps & 0.67 & 0.8 & 4.3 & 3.67 & 2.75 & 3.65 \\
\hline Exotic carps & 20.6 & 24.6 & 26.8 & 22.8 & 12.6 & 16.8 \\
\hline Important catfishes & 23.5 & 28 & 20.8 & 17.7 & 28.3 & 37.6 \\
\hline Other important fishes & 8.72 & 10.4 & 7.15 & 6.11 & 6.4 & 8.49 \\
\hline Miscellaneous & 10.8 & 12.9 & 12.55 & 10.7 & 9.89 & 13.1 \\
\hline
\end{tabular}

Table 5. Variations in the average catch $\left(\mathrm{Kg}\right.$ day $\left.^{-1}\right)$ of major fishery components in the rivers Ken, Paisuni and Tons.

\begin{tabular}{|l|l|l|l|l|l|l|}
\hline Categories & \multicolumn{2}{|l|}{ Ken } & Paisuni & \multicolumn{2}{l|}{ Tons } \\
\hline & $\mathrm{Kg}$. & $\%$ & Kg. & $\%$ & Kg. & $\%$ \\
\hline Major carps & 22.6 & 26.2 & 13.8 & 31.2 & 10.6 & 32.5 \\
\hline Other carps & 2.44 & 2.82 & 0.58 & 1.31 & 1.86 & 5.75 \\
\hline Exotic carps & 17.9 & 20.7 & 9.11 & 20.6 & 2.62 & 8.09 \\
\hline Important catfishes & 25.4 & 29.4 & 7.88 & 17.9 & 8.99 & 27.7 \\
\hline Other important fishes & 7.25 & 8.4 & 7.22 & 16.4 & 3.53 & 10.9 \\
\hline Miscellaneous & 10.7 & 12.4 & 5.58 & 12.3 & 4.87 & 15 \\
\hline
\end{tabular}

Table 6. Monthly variations in fish catch $\left(\mathrm{Kg}\right.$. day $\left.{ }^{-1}\right)$ of important fish species in the river Paisuni.

\begin{tabular}{|l|l|l|l|l|l|l|}
\hline Species & \multicolumn{2}{|l|}{ December } & April & \multicolumn{2}{l|}{ June } \\
\hline & Kg. & $\%$ & Kg. & $\%$ & Kg. & $\%$ \\
\hline Labeo rohita & 4.03 & 10.7 & 0.25 & 0.65 & 0.58 & 0.92 \\
\hline Catlacatla & 2.64 & 6.98 & 0.25 & 0.65 & 1.95 & 3.11 \\
\hline Cirrhinus mrigala & 4.86 & 12.9 & 0.98 & 2.54 & 1.15 & 1.83 \\
\hline Labeo calbasu & 3.64 & 9.63 & 9.23 & 24 & 10.4 & 16.6 \\
\hline Tor tor & 0.38 & 0.99 & 0.41 & 1.08 & 1.15 & 1.83 \\
\hline Cyprinus carpio & 2.8 & 7.41 & 1.08 & 2.8 & 5.05 & 8.06 \\
\hline Ctenopharyngodon idella & 0 & 0 & 0 & 0 & 0 & 0 \\
\hline Hypophthalmichthys molitrix & 2.79 & 7.38 & 6.78 & 17.7 & 12.4 & 19.7 \\
\hline Aorichthysspp. & 4.03 & 10.7 & 3.1 & 8.08 & 4.4 & 7.02 \\
\hline Wallago attu & 1.49 & 3.94 & 2.73 & 7.1 & 4.98 & 7.94 \\
\hline Rita rita & 1 & 2.65 & 1.2 & 3.13 & 2.1 & 3.35 \\
\hline Channa spp. & 0.45 & 1.42 & 0.85 & 2.22 & 1.15 & 1.83 \\
\hline $\begin{array}{l}\text { Notopterus notopterus } \text { and } \\
\text { Chitala chitala }\end{array}$ & 3.89 & 10.3 & 2.85 & 7.43 & 5.13 & 8.18 \\
\hline Mastacembelus armatus & 1.99 & 5.26 & 2.45 & 6.39 & 3.63 & 5.78 \\
\hline Miscellaneous & 3.71 & 9.83 & 6.23 & 16.2 & 8.68 & 13.8 \\
\hline
\end{tabular}


Table 7. Monthly variations in the catch $\left(\mathrm{Kg} \mathrm{day}^{-1}\right)$ of major fishery components in the river Paisuni.

\begin{tabular}{|l|l|l|l|l|l|l|}
\hline Categories & \multicolumn{2}{l|}{ December } & April & \multicolumn{2}{l|}{ June } \\
\hline & Kg. & $\%$ & Kg. & $\%$ & Kg. & $\%$ \\
\hline Major carps & 15.2 & 40.2 & 10.7 & 27.9 & 14.1 & 22.5 \\
\hline Other carps & 0.38 & 0.99 & 0.41 & 1.08 & 1.15 & 1.83 \\
\hline Exotic carps & 5.59 & 14.8 & 7.85 & 20.5 & 17.4 & 27.8 \\
\hline Important catfishes & 6.51 & 17.2 & 7.03 & 18.3 & 11.5 & 18.3 \\
\hline Other important fishes & 6.41 & 17 & 6.15 & 16 & 9.9 & 15.8 \\
\hline Miscellaneous & 3.71 & 9.83 & 6.23 & 16.2 & 8.68 & 13.8 \\
\hline
\end{tabular}

Table 8. Monthly variations in the catch $\left(\mathrm{Kg}\right.$ day $\left.^{-1}, \%\right)$ of important fish species from the river Tons.

\begin{tabular}{|c|c|c|c|c|c|c|c|}
\hline & December & January & February & March & April & May & June \\
\hline & \multicolumn{7}{|c|}{ Catch in weight (Kg.) } \\
\hline Labeo rohita & 0 & 4 & 9.55 & 1.67 & 1.77 & 1.5 & 0.36 \\
\hline Catla catla & 0 & 0 & 4.5 & 1.5 & 3.63 & 0.1 & 0.14 \\
\hline Cirrhinus mrigala & 0 & 5.5 & 3.75 & 3.67 & 1.88 & 2.32 & 0.483 \\
\hline Labeo calbasu & 3 & 1 & 6.67 & 4.13 & 2.8 & 5.86 & 4.083 \\
\hline Tor tor & 9 & 0 & 0 & 0 & 1.8 & 0.6 & 1.65 \\
\hline Cyprinus carpio & 2.5 & 0.5 & 2.75 & 1.64 & 1.29 & 0.07 & 0.45 \\
\hline Ctenopharyngodon idella & 0 & 0 & 4 & 1 & 0.87 & 0.92 & 1.52 \\
\hline Hypophthalmichthys molitrix & 0 & 0 & 0 & 0 & 0 & 0.06 & 0.767 \\
\hline Aorichthysspp. & 7 & 1 & 2 & 7.75 & 2.13 & 6.42 & 6.15 \\
\hline Wallago attu & 2 & 0.9 & 1.13 & 2.4 & 1.07 & 4.12 & 4.767 \\
\hline Rita rita & 0.6 & 1.4 & 2.13 & 3.33 & 2.23 & 1.76 & 2.65 \\
\hline Channaspp. & 2 & 0 & 3.15 & 0.6 & 0.45 & 0.12 & 0.55 \\
\hline NotopterusnotopterusandChitalachitala & 1.8 & 0 & 4.53 & 4.35 & 0.9 & 1 & 1.8 \\
\hline Mastacembelus armatus & 0.1 & 0 & 0.8 & 0 & 1.3 & 0.44 & 0.85 \\
\hline \multirow[t]{2}{*}{ Miscellaneous } & 4 & 14 & 1.23 & 3 & 3.18 & 5.06 & 3.65 \\
\hline & \multicolumn{7}{|c|}{ Catch in percentage (\%) } \\
\hline Labeo rohita & 0 & 14.1 & 20.7 & 4.76 & 6.99 & 4.94 & 1.21 \\
\hline Catla catla & 0 & 0 & 9.73 & 4.28 & 14.4 & 0.33 & 0.47 \\
\hline Cirrhinus mrigala & 0 & 19.4 & 8.11 & 10.5 & 7.42 & 7.64 & 1.62 \\
\hline Labeo calbasu & 9.38 & 3.53 & 14.4 & 11.8 & 11.1 & 19.3 & 13.7 \\
\hline Tor tor & 28.1 & 0 & 0 & 0 & 7.12 & 1.98 & 5.52 \\
\hline Cyprinuscarpio & 7.81 & 1.77 & 6.0 & 4.68 & 5.12 & 0.23 & 1.51 \\
\hline Ctenopharyngodon idella & 0 & 0 & 8.65 & 2.85 & 3.43 & 3.03 & 5.09 \\
\hline Hypophthalmichthys molitrix & 0 & 0 & 0 & 0 & 0 & 0.2 & 2.56 \\
\hline Aorichthys spp. & 21.9 & 3.53 & 4.33 & 22.1 & 8.40 & 21.2 & 20.6 \\
\hline Wallago attu & 6.25 & 3.18 & 2.45 & 6.85 & 4.22 & 13.6 & 16.0 \\
\hline Rita rita & 1.88 & 4.95 & 4.62 & 9.51 & 8.83 & 5.8 & 8.87 \\
\hline Channa spp. & 6.25 & 0 & 6.81 & 1.71 & 1.78 & 0.4 & 1.84 \\
\hline $\begin{array}{l}\text { Notopterus notopterus and Chitala } \\
\text { chitala }\end{array}$ & 5.63 & 0 & 9.81 & 12.4 & 3.56 & 3.29 & 6.03 \\
\hline Mastacembelus armatus & 0.31 & 0 & 1.73 & 0 & 5.14 & 1.45 & 2.85 \\
\hline Miscellaneous & 12.5 & 49.5 & 2.67 & 8.56 & \begin{tabular}{|l|}
12.6 \\
\end{tabular} & 16.7 & 12.2 \\
\hline
\end{tabular}


Table 9. Monthly variations in the catch $\left(\mathrm{Kg}_{\text {. day }}{ }^{-1}\right)$ major fishery components from the river Tons.

\begin{tabular}{|l|l|l|l|l|l|l|l|}
\hline & \multicolumn{9}{l}{ Fish catch in Kg. day $^{-1}$} \\
\hline Categories & December & January $^{-1}$ & February & March & April & May & June \\
\hline Major carps & 3.0 & 10.5 & 24.5 & 11 & 10.1 & 9.78 & 5.07 \\
\hline Other carps & 9.0 & 0 & 0 & 0 & 1.8 & 0.6 & 1.65 \\
\hline Exotic carps & 2.5 & 0.5 & 6.78 & 2.64 & 2.16 & 1.05 & 2.74 \\
\hline Important catfishes & 9.6 & 3.3 & 5.27 & 13.5 & 5.43 & 12.3 & 13.6 \\
\hline Other important fishes & 3.9 & 0 & 8.48 & 4.95 & 2.65 & 1.56 & 3.2 \\
\hline Miscellaneous & 4.00 & 14.0 & 1.23 & 3.0 & 3.18 & 5.06 & 3.65 \\
\hline & Fish catch in percentage \\
\hline Major carps & 9.38 & 37.1 & 52.9 & 31.3 & 39.8 & 32.2 & 17 \\
\hline Other carps & 28.1 & 0 & 0 & 0 & 7.12 & 1.98 & 5.52 \\
\hline Exotic carps & 7.81 & 1.77 & 14.7 & 7.53 & 8.54 & 3.46 & 9.16 \\
\hline Important catfishes & 30 & 11.7 & 11.4 & 38.5 & 21.5 & 40.5 & 45.4 \\
\hline Other important fishes & 12.2 & 0 & 18.4 & 14.1 & 10.5 & 5.14 & 10.7 \\
\hline Miscellaneous & 12.5 & 49.5 & 2.67 & 8.56 & 12.6 & 16.7 & 12.2 \\
\hline
\end{tabular}

The pooled average catch was little higher for the major carps $\left(32.5 \%, 10.6 \mathrm{Kg}_{\text {day }^{-1}}\right)$ compared with important catfishes group $(27.7 \%, 8.99 \mathrm{Kg})$ and other important fishes $\left(10.9 \%, 3.53 \mathrm{Kg} \mathrm{day}^{-1}\right)$. Other carp formed a small share $(5.75 \%, 1.86 \mathrm{Kg}$ day $\left.^{-1}\right)$. Exotic carps and miscellaneous group varied from $2.62 \mathrm{Kg}$ day $^{-1}$ and $4.87 \mathrm{Kg}$ day $^{-1}$ (Table 5), thus contributing $8.09 \%$ and $15.0 \%$, respectively (Fig. 6).

Observations on the total landings show that the average catch day $^{-1}$ of the Ken river was dominated by $C$. carpio followed by Aorichthys spp. and miscellaneous fish. In contrast the Paisuni R. was dominated by L. calbasu followed by $H$. molitrix and miscellaneous while the latter group dominated over Aorichthys spp and $L$. calbasu in the Tons R. The fishery trend was quite distinct in the rivers under observation, owing to dominance of the exotic carp C. carpio in the Ken, L. calbasu in the Paisuni $\mathrm{R}$ while miscellaneous group in the Tons river. This difference can be attributed to the invasion of the exotic carp $C$. carpio in the Yamuna river which along with small share of other exotic carp formed $17.8 \%$ of the total landing at Allahabad (Anon 2003).

After common carp (C. carpio) and Nile Tilapia (Oreochromis niloticus), the miscellaneous and catfishes are emerging as the major fishery in indigenous format not only in the Ganga and Yamuna but also in the tributaries under observation (Anon 2002, 2003, Mayank and
Dwivedi 2015, Tripathi et al 2017). Earlier, the major carps $(36.26 \%)$ and the cat fishes $(36.17 \%)$ had a similar share and miscellaneous accounted for $26.33 \%$ only (Anon 1976). Later, Gupta and Tyagi (1992) recorded that the miscellaneous species comprised the major share $(50.50 \%)$ while Aorichthys aor and A. seenghala together accounted for $16.81 \%$ at Allahabad. Few years ahead, Singh et al (1998) found that A. aor and A. seenghala were dominant species (45.2\%) compared with miscellaneous $(28.2 \%)$ and $L$. calbasu (14.6\%) in the Ganga and the Yamuna at Allahabad. The L. rohita, C. catla and C. mrigala contributed small proportions $2.5 \%, 3.2 \%$ and $1.5 \%$, respectively showing a decline in their fishery. The miscellaneous group, the share of which declined from $75.62 \%$ in 1985 to $48.33 \%$ in 1986, primarily dominated the fishery of the Ganga at Patna. Aorichthys aor, A. seenghala and $W$. attu which contributed in sizeable amounts among catfish increased from 1985 to 1986 (from around 10 to $15 \%$, Kumar 1996). Mishra and Moza (2001) reported that the overall fish population in the Yamuna river (Delhi to Etawah), showed dominance of large size catfishes (49.26\%) followed by major carp (28.54\%). Aorichthys spp. and W. attu contributed $29.38 \%$ and $19.87 \%$, respectively. At Kanpur too the catfishes $(42.2 \%)$ and others $(29.6 \%)$ have dominated the Indian major carps (18.9\%) and exotic carps $9.3 \%$ in the Ganga. 
The landing composition has fluctuated from year to year at Sadiapur, Allahabad (Anon 1976, 1991, 2002, 2003). In 1976 L. calbasu, C. mrigala,C. catla, and $L$. rohita contributed 15.68, 11.60, 3.30 and 4.72 tonnes, respectively while Aorichthys aor and A. seenghala 19.27 tonnes and miscellaneous 36.17 tonnes. At this point of time major carps and the cat fishes occurred in equal proportions (36.26\%, and 36.17\%, respectively). In 1990-1991 the share of Aorichthys aor and A. seenghala increased to $26.18 \%$ and $52.31 \%$, respectively. $C$. mrigala, C. catla, L. rohita and L. calbasu contributed $2.53 \%, 2.82 \%, 2.76 \%$ and $10.81 \%$, respectively (Anon 1991). During 2001-2002 the miscellaneous fish (72.0\%) dominated over the catfishes (A. aor and A. seenghala 14.2\%) and carps (C. mrigala, C. catla, L. rohita and $L$. calbasu, $1.40 \%, 3.1 \%, 2.9 \%$ and $1.4 \%)$. W. attu and Hilsa ilisha contributed very small proportions $1.6 \%$ and $1.8 \%$, respectively. In 2002-2003 the share of miscellaneous fish $(62.7 \%)$ declined, that of the exotic carps increased to $17.8 \%$ while the catfishes $(13.1 \%)$ and the Indian major carps $(6.4 \%)$ remained stable. In the middle stretch of the Ganga river system (Agra to Bhagalpur) earlier also 'others' contributed sizeably (25.4\%). C. mrigala was dominant (18.4\%) in the carp catch. A.aor and A. seenghala $17.5 \%$ occurred in similar proportions and $L$. calbasu contributed small proportion (4.9\%) of the total catch. L. rohita and C. catla contributed more or less similarly $8.5 \%$ and $8.6 \%$ (Jhingran 1982).

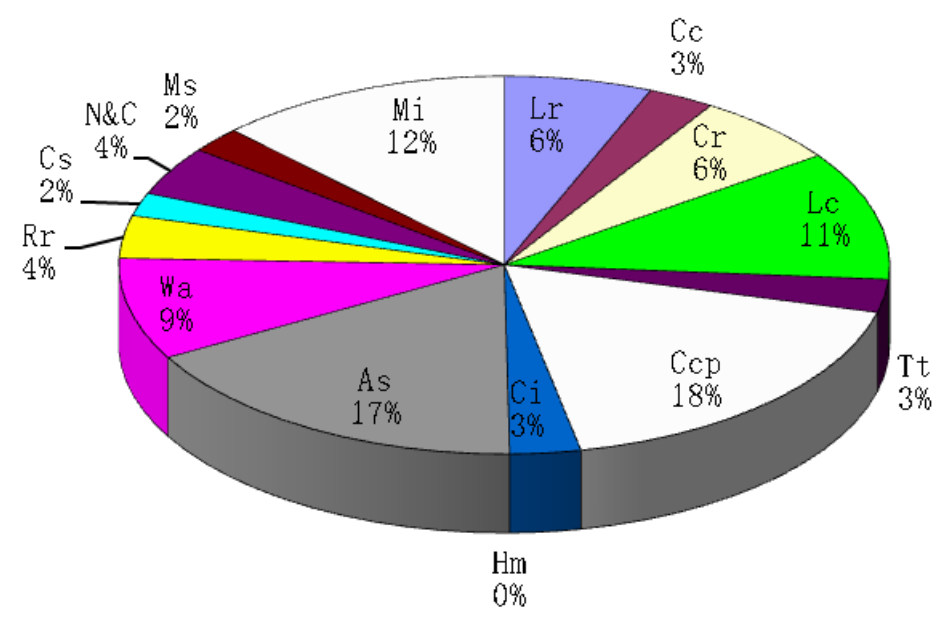

Fig. 1.Average annual catch day ${ }^{-1}$ of fish species from the river Ken at Banda.Acronyms as in Table 11. 


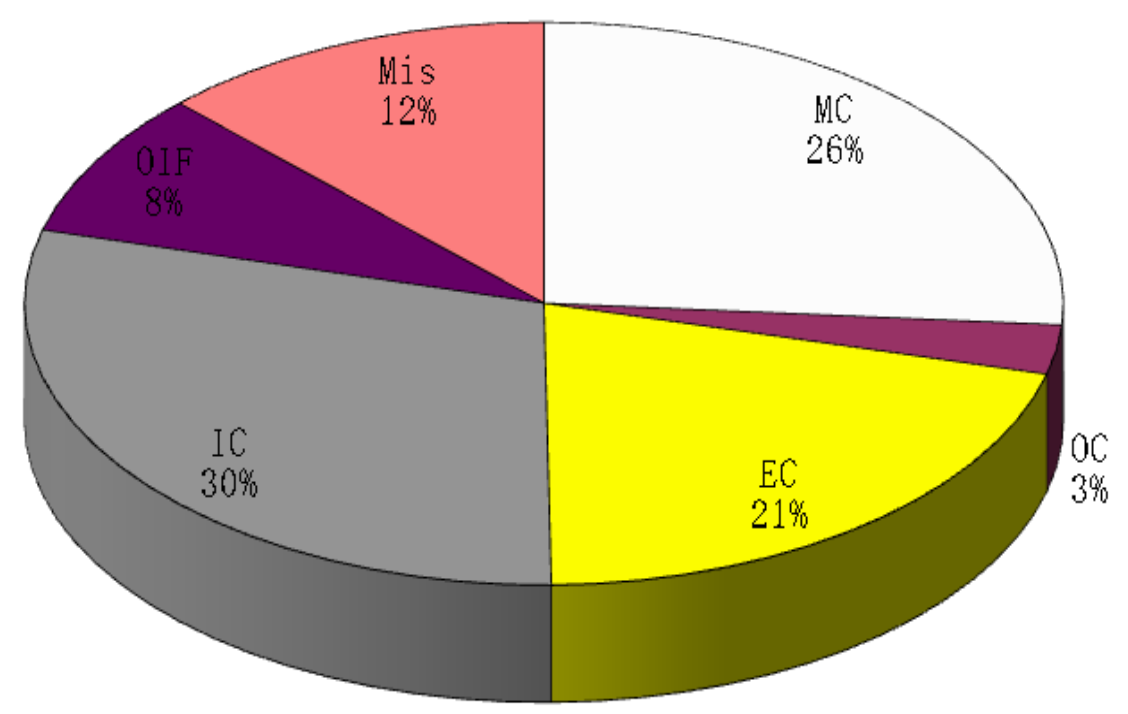

Fig. 2. Average annual catch day ${ }^{-1}$ of major groups from the river Ken at Banda.

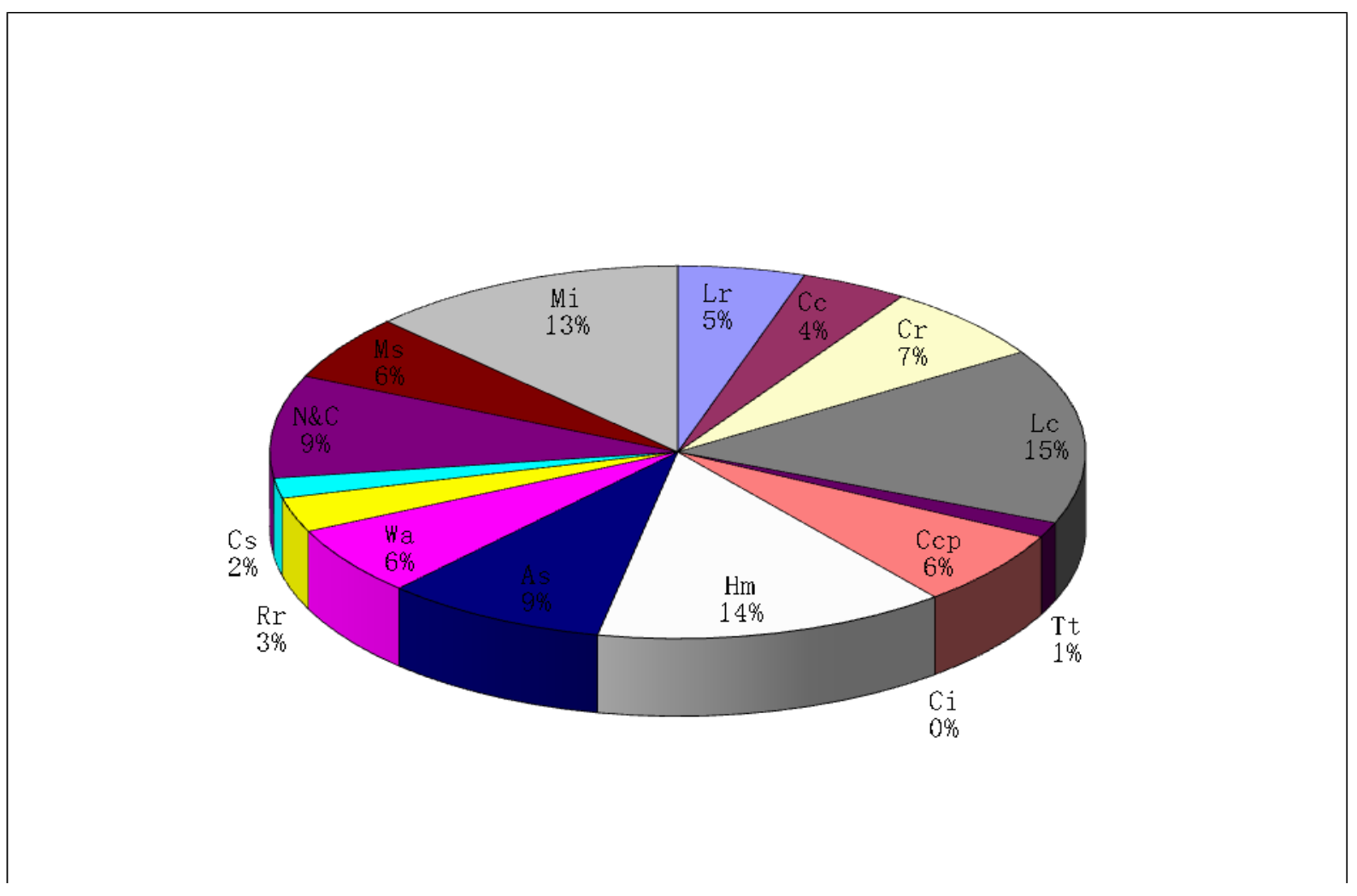

Fig. 3. Average annual catch day ${ }^{-1}$ of fish species from the river Paisuni at Karwi.Acronyms as in Table 11. 


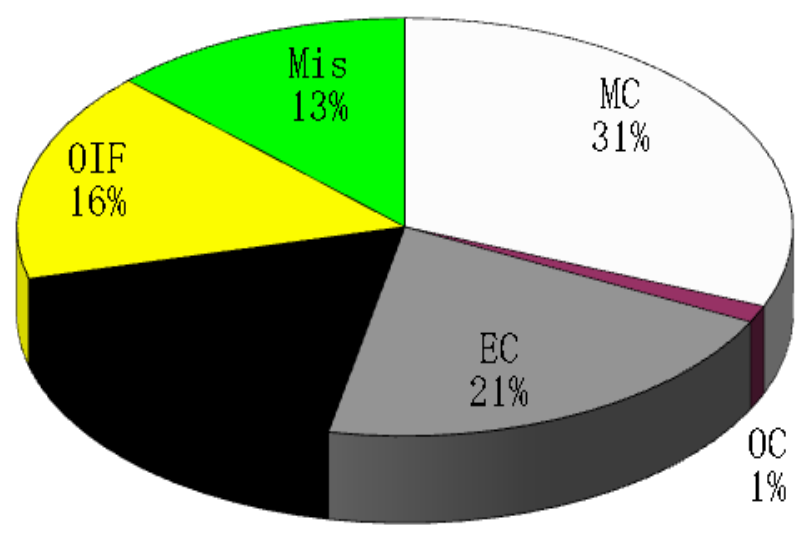

Fig. 4. Average annual catch day ${ }^{-1}$ of major groups from the Paisuniriver at Karwi.

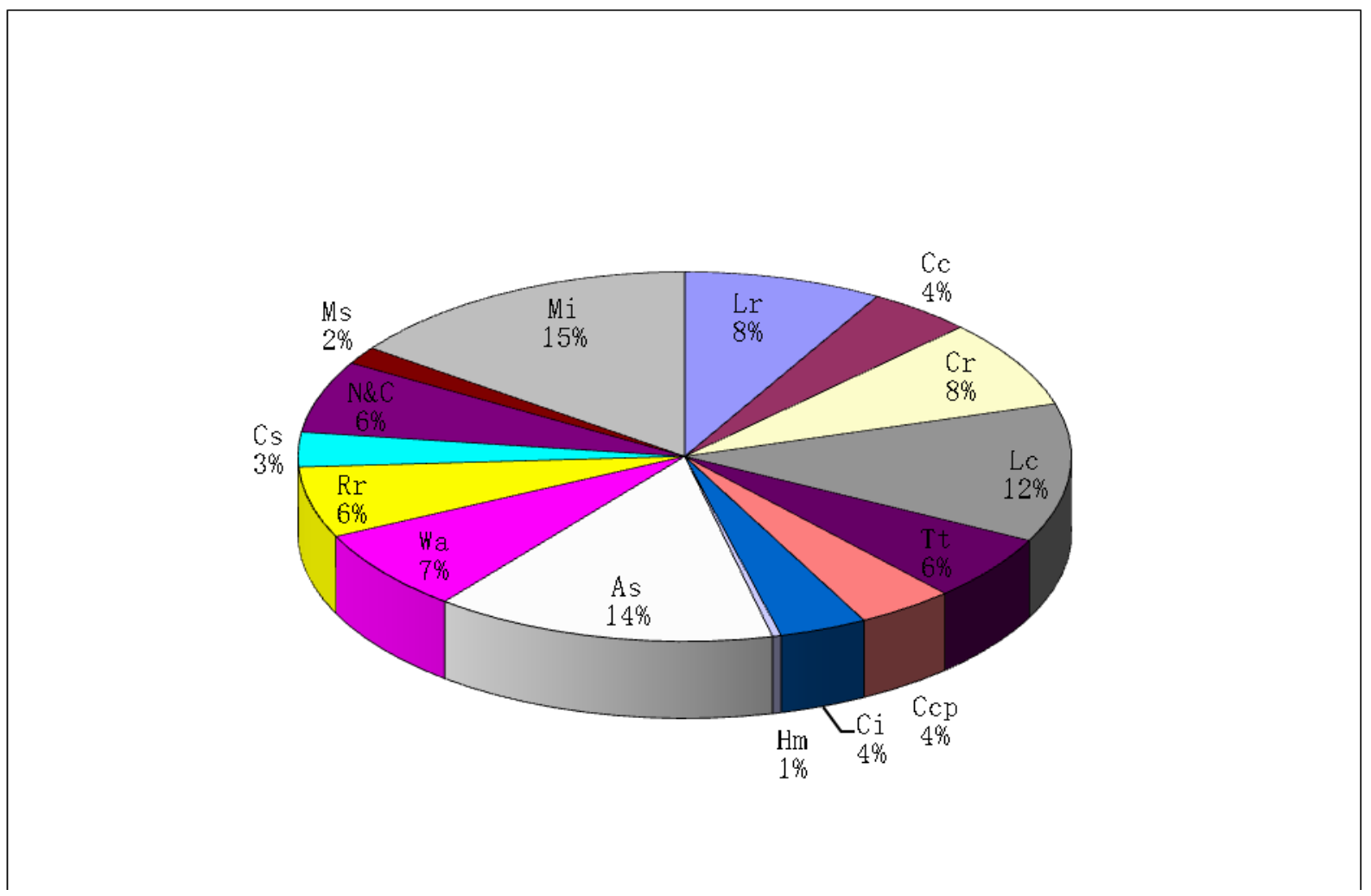

Fig. 5. Average annual catch day ${ }^{-1}$ of fish species from the Tons river at Chakghat. Acronyms as in Table 11. 


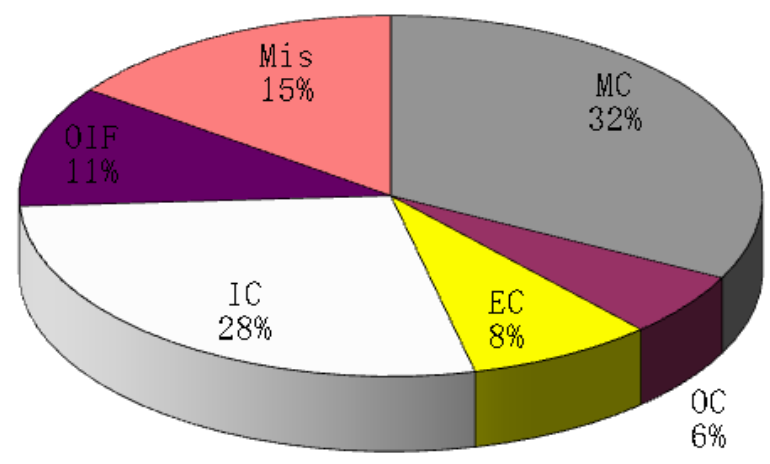

Fig. 6. Average annual catch day ${ }^{-1}$ of major groups from the Tons river at Chakghat.

In the major carp category the average catch day $^{-1}$ of $L$. calbasu dominated over $L$. rohita and C. mrigala in the Ken, Paisuni as well as the Tons R. T. tor catch was recorded to be less than $3 \%$ in the Ken and Paisuni R. while $5.75 \%$ in the Tons. The average catch day ${ }^{-1}$ of $L$. calbasu varied from 11.0 to $14.8 \%$ at the landing centers of these rivers compared with 6.17 to $7.75 \%$ in case of $C$. mrigala and much lower in other carps including L. rohita (4.88 to $8.3 \%)$ and C. catla (2.8 to $4.35 \%)$. Thus, L. calbasu was contributing immensely to carp catch in all these rivers. Among the carps $L$ calbasu has occupied a prominent position in the catch (Jhingran and Ghosh 1978) and has emerged as principal component (L. calbasu 17.15\%) in the Allahabad region (Gupta and Tyagi 1992). L. rohita, C. catla and $W$. attu contributed very small proportions, $2.06 \%, 3.06 \%$ and $3.58 \%$ respectively. In the Ganga at Patna, the Indian major carp accounted for small proportion during $2.91 \%, 1.31 \%, 1.63 \%$ and $0.61 \%$ for C. catla, L. rohita, C. mrigala and L. calbasu, respectively while in 1986 proportion increased, C. catla (7.45), L. rohita (4.61\%), C. mrigala $(1.80 \%)$ and L. rohita $(5.04 \%)$. The $L$. calbasu share increased nearly 8 times in 1986
(Kumar 1996). Mishra and Moza (2001) reported that L.calbasu had more share (11.23\%) than the Indian major carp, L. rohita $(5.41 \%)$ and $C$. mrigala (9.03\%). Other catfish and murrels (Channa spp.) too formed substantial fishery $(8.15 \%$ and $3.95 \%)$. Miscellaneous species contributed $7.36 \%$ of the total population, particularly Puntius sp. and Chela spp.

Thus, the catch structure has altered since 1970's. In the $5^{\text {th }}$ decade the capture fishery of the Ganga river was dominated by $C$. mrigala among the major carp and Aorichthys aor among the catfishes. Labeo calbasu accounted for only $4.3 \%$ of total fishery at Buxar (Jhingran 1982). The contribution of miscellaneous group of fishes in total catch has almost doubled in the recent years in the Ganga and Yamuna rivers, as compared to sixties when it formed about $25 \%$ of the catch, signaling towards the substitution of economically important fishes by low priced fishes (Seth 1996, Seth and Panwar 2001).

Seth and Katiha (2001) opined that the decline of Gangetic carp population in the Ganga river system has brought tremendous fishing stress on its natural riverine stock. It points towards the Over exploitation of its riverine population 
coupled with wanton killing of brood stock and in turn the young ones. The percentage share of carps, large siluroids and miscellaneous fish species has changed drastically and interchanged their position in total catch. In sixties, it favored carps with over $46 \%$ share. In seventies and eighties their share declined to around $32 \%$ as it was replaced mainly by miscellaneous fish species (42-49\%) and to some extent by siluroids. During last one decade, the share of miscellaneous fish reached the highest at above 54\%, while for carps it reduced to minimum of $12 \%$.

The quantity of the fish caught in many of the world's rivers is declining and species assemblages are being modified with the disappearance of some native species and the established of exotics (Welcomme 2006 a, Pathak et al 2011, Dwivedi et al 2016, Mayank et al 2018). Capture fisheries have reached or passed their sustainable yield in many rivers (Welcomme 2006 b, Nautiyal et al 2013). Fishermen prefer to land large sized fish as it fetches higher price, which goes to show that fishing is market oriented thus influencing the landing pattern. When large sized fish become few in the stock fishermen land even the smallest size as was evident in L. rohita. The minimum size in catch was $10.5 \mathrm{~cm}$ for $L$. rohita compared with $16.0 \mathrm{~cm}$ for $L$. calbasu and $18.0 \mathrm{~cm}$ for $T$. tor. Fishing is the primary income generating activity for most families living along the bank of river (Asante 2006, Tiwari et al 2016). Though the fish markets at Banda (Kenriver), Karwi (Paisuni river) and Sadiapur/Gaughat (Tons river) were located far from each other, the pricing patterns were similar. Market prices depend on the weight (size) of the fish. Large-sized fishes were sold at higher price indicating that they have more economic value than the small-sized fishes of the same species. The important catfishes commanded highest price ranging from Rs. 40 to $100 \mathrm{Kg}^{-1}$. The feather back and eels had low price tags (Rs. 25 to $\left.50 \mathrm{Kg}^{-1}\right)$.

Table 10. Price of fish $\mathrm{Kg}^{-1}$ from the fish market at Banda, Karwi and Sadiapur for the rivers Ken, Paisuni and Tons, respectively.

\begin{tabular}{|c|c|c|c|c|c|c|}
\hline \multirow{2}{*}{$\begin{array}{l}\text { Category } \backslash \text { Fishes } \\
\text { Species }\end{array}$} & \multicolumn{6}{|c|}{ Categories based on weight of fishes (in Kg.) } \\
\hline & $<0.5 \mathrm{Kg}$ & $<1.0 \mathrm{Kg}$. & $<1.5 \mathrm{Kg}$. & $<2.0 \mathrm{Kg}$. & $<3.0 \mathrm{Kg}$. & $<4.0 \mathrm{Kg}$ \\
\hline \multicolumn{7}{|l|}{ Major carps } \\
\hline Labeo rohita & 40 & 50 & 55 & 60 & 75 & 90 \\
\hline Catla catla & 35 & 45 & 50 & 55 & 60 & 75 \\
\hline Cirrhinus mrigala & 35 & 45 & 50 & 55 & 60 & 75 \\
\hline Labeo calbasu & 30 & 40 & 45 & 50 & 60 & 0 \\
\hline \multicolumn{7}{|l|}{ Other carp } \\
\hline Tor tor & 35 & 45 & 50 & 55 & 60 & 70 \\
\hline \multicolumn{7}{|l|}{ Exotic carps } \\
\hline Cyprinus carpio & 30 & 35 & 45 & 50 & 55 & 65 \\
\hline Ctenopharyngodon idella & 35 & 40 & 45 & 50 & 60 & 70 \\
\hline $\begin{array}{l}\text { Hypophthalmichthys } \\
\text { molitrix }\end{array}$ & 35 & 40 & 45 & 50 & 60 & 70 \\
\hline \multicolumn{7}{|l|}{ Important catfishes } \\
\hline Aorichthysspp. & 40 & 50 & 60 & 70 & 80 & 100 \\
\hline Wallago attu & 35 & 45 & 50 & 55 & 60 & 80 \\
\hline Rita rita & 35 & 45 & 50 & 55 & 60 & 0 \\
\hline \multicolumn{7}{|l|}{ Other important species } \\
\hline Channa spp. & 30 & 35 & 50 & 60 & 70 & 0 \\
\hline Notopterus sps & 25 & 35 & 45 & 50 & 0 & 0 \\
\hline Mastacembelus armatus & 25 & 40 & 0 & 0 & 0 & 0 \\
\hline Miscellaneous & \multicolumn{6}{|c|}{$15-40 \mathrm{Kg}^{-1}$} \\
\hline
\end{tabular}


Among the major carps, maximum price was commanded by $L$. rohita followed by $C$. catla and $C$. mrigala. The market price of $L$. rohita varied from Rs. 40 to $90 \mathrm{Kg}^{-1}$ for fishes weighing $<0.5$ $\mathrm{Kg}$ to $<4.0 \mathrm{Kg}$. In case of the exotic carps it varied from Rs. 30 to 70 for fishes $<0.5$ to $<4.0$ $\mathrm{Kg}$, respectively. In miscellaneous group a range of Rs. 25 to $40 \mathrm{Kg}^{-1}$ was recorded according to the species and size (Table 10). Two measures of central tendency, the mean and the median were computed to ascertain that the value represented the data. Except for some species the mean was slightly higher than the median and their values differed slightly (Figs. 7 a-b). The Aorichthys spp. commanded the highest median price of Rs. 65.0 $\mathrm{Kg}^{-1}$. The carps had lesser market value. Among them $L$. rohita was sold at the median price of Rs. $57.5 \mathrm{Kg}^{-1}$ compared with Rs. 52.5 for the other carp, being least (Rs. $42.5 \mathrm{Kg}^{-1}$ ) for $L$. calbasu (Fig. 7a). Steady pricing pattern i.e. less variation was observed for all carps except $L$. rohita among the major carps. Considerable variation was observed in the market price of each species, especially Channa spp, $R$. rita, Aorichthys spp., $L$. calbasu and L. rohita. This was reflected in the mean and standard error values (Fig. 7 b). The minimum-maximum and range were also indicative. Kurtosis shows negative value in $L$. rohita and T. tor while positive in L. calbasu. Skewness was negative in $L$. calbasu while positive in L. rohita and T. tor (Table 11).

Table 11. Descriptive statistics for pricing pattern in fish market at Banda, Karwi and Sadiapur in case of the Ken, Paisuni and Tons rivers, respectively.

\begin{tabular}{|c|c|c|c|c|c|c|c|c|c|c|c|c|c|c|}
\hline Descriptives & $L r$ & $C c$ & $\mathrm{Cm}$ & $L c$ & $T t$ & $C c$ & $C i$ & $H m$ & $A \mathrm{~s}$ & $W a$ & $R r$ & $C \mathrm{~s}$ & $\begin{array}{l}N \& \\
C\end{array}$ & $\mathrm{Mi}$ \\
\hline Mean & 61.7 & $\begin{array}{l}53 . \\
3\end{array}$ & $\begin{array}{l}53 . \\
3\end{array}$ & 37.5 & 52.5 & $\begin{array}{l}46 . \\
7\end{array}$ & 50 & 50 & $\begin{array}{l}66 . \\
7\end{array}$ & $\begin{array}{l}54 . \\
2\end{array}$ & 40.8 & $\begin{array}{l}40.8 \\
3\end{array}$ & 25.8 & 10.8 \\
\hline $\begin{array}{l}\text { Standard } \\
\text { Error } \\
\end{array}$ & 7.38 & $\begin{array}{l}5.5 \\
8 \\
\end{array}$ & \begin{tabular}{|l|}
5.5 \\
8 \\
\end{tabular} & 8.54 & 4.96 & $\begin{array}{l}5.2 \\
7 \\
\end{array}$ & 5.32 & 5.32 & $\begin{array}{l}8.8 \\
2 \\
\end{array}$ & $\begin{array}{l}6.2 \\
5 \\
\end{array}$ & 8.98 & $\begin{array}{l}10.1 \\
9 \\
\end{array}$ & 8.89 & 7.12 \\
\hline Median & 57.5 & $\begin{array}{l}52 . \\
5\end{array}$ & $\begin{array}{l}52 . \\
5\end{array}$ & 42.5 & 52.5 & $\begin{array}{l}47 . \\
5\end{array}$ & 47.5 & 47.5 & 65 & $\begin{array}{l}52 . \\
5\end{array}$ & $\begin{array}{l}47.5 \\
150\end{array}$ & $\begin{array}{l}42.5 \\
150\end{array}$ & $\begin{array}{l}30 \\
135\end{array}$ & 32.5 \\
\hline Minimum & 40 & 35 & 35 & 30 & 35 & 30 & 35 & 35 & 40 & 35 & 35 & 30 & 25 & 25 \\
\hline Maximum & 90 & 75 & 75 & 60 & 70 & 65 & 70 & 70 & 100 & 80 & 60 & 70 & 50 & 40 \\
\hline Range & 50 & 40 & 40 & 30 & 35 & 35 & 35 & 35 & 60 & 45 & 25 & 40 & 25 & 15 \\
\hline Kurtosis & $\overline{0} .24$ & $\begin{array}{l}0.5 \\
9\end{array}$ & $\begin{array}{l}0.5 \\
9 \\
\end{array}$ & 2.03 & $\overline{0}-01$ & $\begin{array}{l}- \\
0.9\end{array}$ & $\begin{array}{l}- \\
0.65\end{array}$ & $-\overline{0} .65$ & $\begin{array}{l}- \\
0.3\end{array}$ & $\begin{array}{l}1.2 \\
7 \\
\end{array}$ & 2.97 & 0.33 & $\begin{array}{l} \\
1.97\end{array}$ & $\begin{array}{l}- \\
0.05\end{array}$ \\
\hline Skewness & 0.66 & $\begin{array}{l}0.4 \\
3\end{array}$ & $\begin{array}{l}0.4 \\
3 \\
\end{array}$ & $\begin{array}{l}- \\
1.29\end{array}$ & 0 & $\begin{array}{l}0.0 \\
8 \\
\end{array}$ & 0.61 & 0.61 & $\begin{array}{l}0.4 \\
6\end{array}$ & 0.8 & $\begin{array}{l}- \\
1.67\end{array}$ & $\begin{array}{l}- \\
0.71\end{array}$ & $\begin{array}{l}- \\
0.36\end{array}$ & 1.28 \\
\hline
\end{tabular}

\section{Acronyms}

$\mathrm{Lr}=$ Labeo rohita $; \quad \mathrm{Cc}=$ Catla catla $; \mathrm{Cr}=$ Cirrhinus mrigala $; \mathrm{Lc}=$ Labeo calbasu, $\mathrm{Tt}=$ Tor tor $; \mathrm{Ccp}=$ Cyprinus carpio $; \mathrm{C}=$ Ctenopharyngodon idella $; \mathrm{Rr}=$ Rita rita $; \mathrm{Hm}=$ Hypophthalmichthys molitrix $; \mathrm{A}=$ Aorichthys spp; $\mathrm{Wa}=$ Wallago attu $\mathrm{Cs}=$ Channa $\mathrm{spp} ; \mathrm{N} \& \mathrm{C}=$ Notopterus $\quad \& \quad$ Chitala $; \quad \mathrm{Ms}=$ Mastacembelus armatus; $\mathrm{M}=$ Miscellaneous.MC= Major carps; OC= Other carp;EC $=$ Exotic carps, $\mathrm{IC}=$ Important catfishes; OIF= Other important fishes;Mis= Miscellaneous; De= December;Jan= January;Feb= February; A= April; Ju= June 


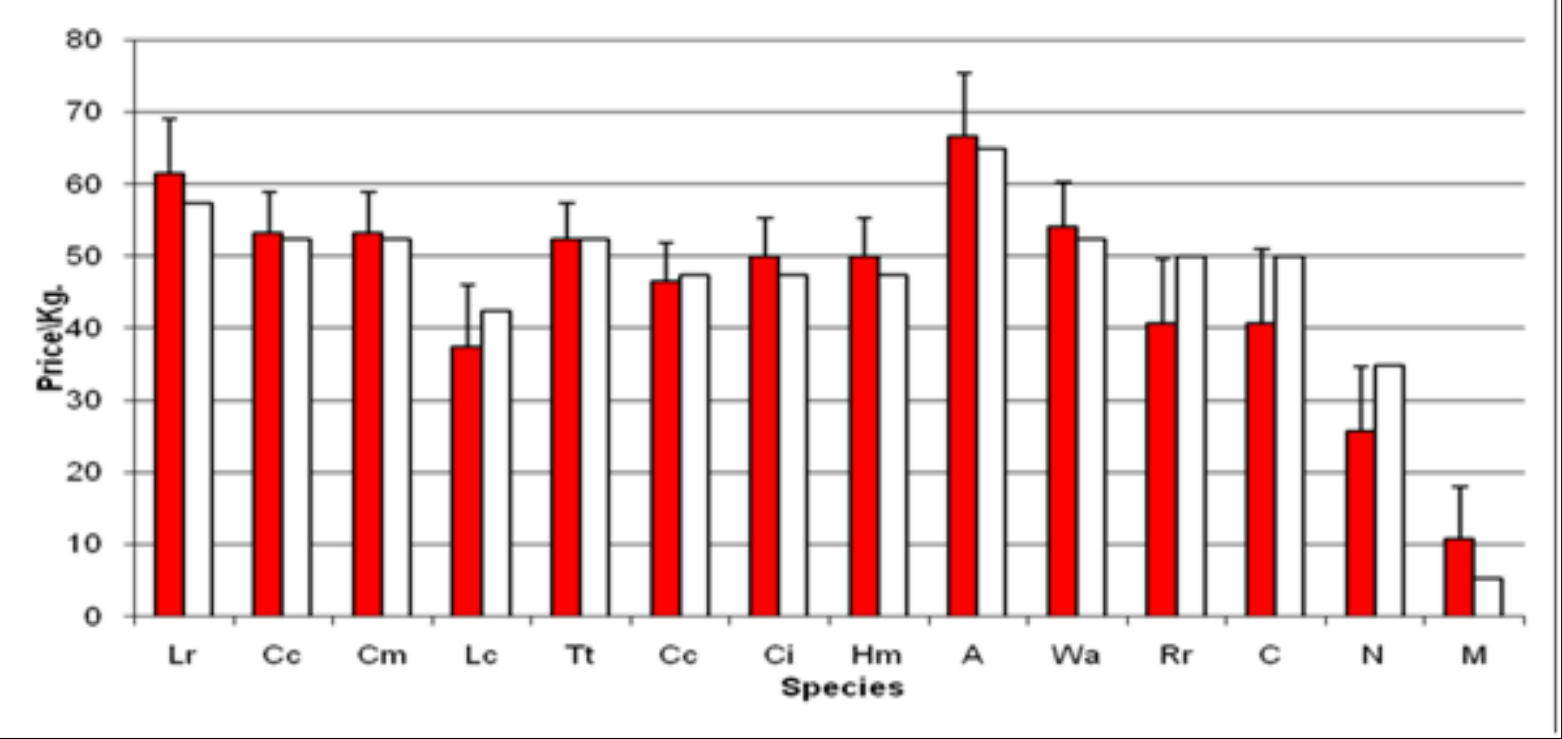

Fig. 7a.The bars depicting the mean (bars with error bars) and median price of fishes. The median price was higher than mean price in the L. calbasu, C. carpio, R. rita, C.spp and N. notopterus and C. chitala. Acronyms as in Table 11.

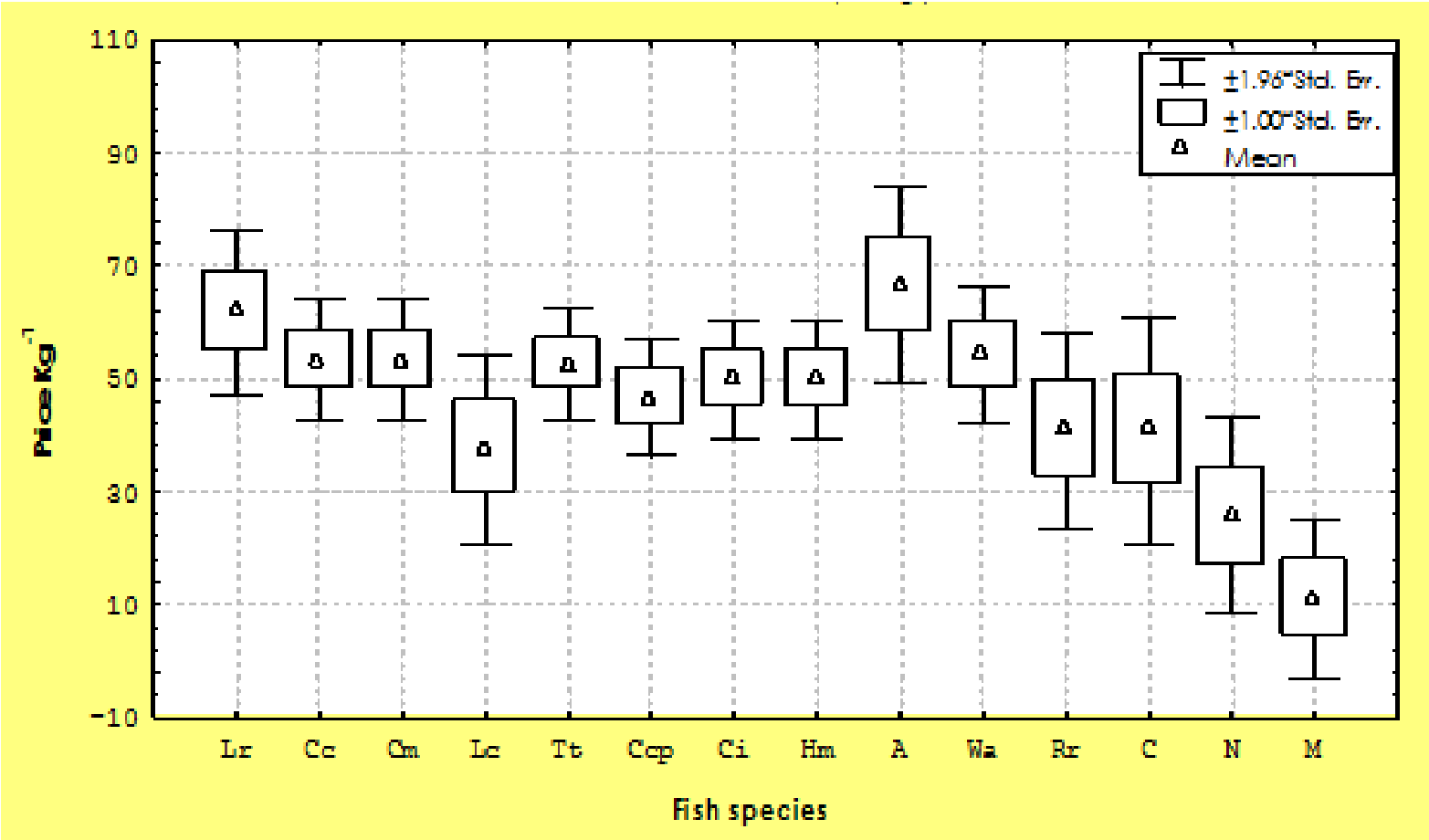

Fig. 7b.The box and whisker showing mean price of important fishes. Acronyms as in Table 1 
Among the fish landings in the Ken, Paisuni and Tons R. maximum price was recorded for $L$. rohita among carps and Aorichthys spp. among catfishes. The mean price was $66.7 \mathrm{Kg}^{-1}$ for Aorichthys spp. The mean price for the major carps $L$. rohita, C. catla, $C$. mrigala and $L$. calbasu was estimated to be 61.7, 53.3, 53.3 and $37.5 \mathrm{Kg}^{-1}$ while that of $T$. tor and C. carpio was 52.5 and $46.7 \mathrm{Kg}^{-1}$, respectively. In the present study L. rohita and Aorichthys spp. were highly priced (mean value) fish. T. tor and L. calbasu were considered to be of moderate economic value of which latter was least priced. C. catla, $C$. mrigala and $W$. attu were identically priced. The information on the market price was used to classify the fishes into three categories based on the median and mean price (i) high economic value Aorichthys spp, L. rohita (ii) moderate economic value, C. catla, C. mrigala, T. tor, $C$. idella, H. molitrix, W. attu,R. rita and (iii) low economic value, L. calbasu, C. carpio, Channaspp, $N$. notopterus, $C$. chitala and Mastacembelus spp. Since carps were the focus for the present study, one species from each category respectively, was considered viz. $L$. rohita, T. tor and L. calbasu. The preferences are indeed creating a pressure on the fishery leading to overexploitation.

Observation made during 1986-1990 and 19911995 (Katiha et al 1998) showed that the carps commanded higher price (Rs. 21.69 and 33.42) than catfishes (Rs 18.77 and 30.52). They found that among the commercially important species, the percentage increase in prices and annual growth rates were higher for the catfishes (62.59 and $10.69 \%)$ than carps (54.10 and $8.91 \%)$. Across different size groups of catfishes and carps, the highest increase in fish price was for large sized fishes at $13.91 \%$ and $9.13 \%$ as compared to $11.55 \%$ and $5.31 \%$ for medium and $10.88 \%$ and $8.49 \%$ for small sized fishes, respectively. The reduction in quantum of the landings and increase in prices for riverine fish harvest maintained almost status quo for its value. Sultan (2005) observed that the fish market of Uttar Pradesh suffer from a weakness in the most essential component, that of organized marketing.
The fishermen need to be paid remunerative prices on one hand and make fish product available to the consumer at reasonable price on the other. Wholesale markets are very few and retailing unorganized. The fishery sector is considered to be more organized where the catch comes to the whole-sale dealer and less organized or unorganized if fishermen or contractors dispose of the catch locally. There is an organized market for the sale of fishes in case of the Ken (at Banda) only, though some fishermen resort to direct selling of the catch. In case of Paisuni catch is disposed of locally or at fish market in Karwi, while in Tons the catch is brought to Allahabad (Sadiapur) or disposed of locally.

In India, the fish catch is primarily marketed in fresh condition in case of riverine fishery. At present, there is no organized body at national level to regulate and channelize fish market in the country. The fish trade is mostly dominated by the middlemen. The fresh water fish marketing is more or less constant (64.2 to 71.7\%) from 1977 to 1999 (Sisodia 2001). Fish price depends on the weight (Dwivedi et al 2004). The increase in price across small to large size groups was also observed by Katiha and Chandra (1990) and Mayank and Dwivedi (2015).

The nutritive value of all species of fish may be almost same but there are different types of market demand and prices for various species (Kurien and Mathew 1982). The price of fish also affects the landing of the fishes through fishing preferences and they change the composition of species in the river (Singh et al 1998, Nautiyal et al 2005, Dwivedi and Nautiyal 2010). A species is harvested on a local scale and market is established, providing profit. Others then become interested in exploiting the species to get a share of the profit. As the stocks start to decline and become difficult to harvest, raising prices for the consumer and competition among the harvesters (Pullin, 2002).

\section{Acknowledgements}

Acknowledgements are due to UGC for fellowship under $\mathrm{Ph}$. D. program to co-author. Authors thank Late Prof H R Singh Head, 
Department of Zoology and former Vice Chancellor University of Allahabad, for academic support.

\section{References}

Allan, J.D., R. Abell, Z. Hogan, C. Revenga, B.W. Taylor, et al. (2005) Overfishing of inland waters. Bioscience,55: 1041-1051.

Anon, (1976).(Annual Report), Central Inland Fisheries Research Institute (ICAR), Barrackpore, Calcutta, West Bengal.

Anon, (1991). (Annual Report), Central Inland Capture Fisheries Research Institute (ICAR), Barrackpore, Calcutta West Bengal, pp 31-32.

Anon, (2002).(Annual Report), Central Inland Fisheries Research Institute (ICAR), Barrackpore, Kolkata West Bengal, pp 16.

Anon, (2003).(Annual Report), Central Inland Fisheries Research Institute (ICAR), Barrackpore, Kolkata West Bengal, pp 48.

Asante, F.A. (2006). Socio-economics of fisheries dependent communities in the Volta Basin of Ghana. Internatn. J. Ecol. Environ. Sci., 32(1): 127-132.

Dwivedi A. C.and P. Nautiyal (2010).Population dynamics of important fishes in the Vindhyan region, India. LAP LAMBERT Academic Publishing GmbH \& Co. KG, Dudweiler Landstr. 99, 66123 Saarbrucken, Germany, Pp. 220.

Dwivedi, A.C. and P. Nautiyal (2012).Stock assessment of fish species Labeo rohita, Tor tor and Labeo calbasu in the Rivers of Vindhyan region, India. J.Environ. Biol. 33: 261-264.

Dwivedi, A.C., A. S. Mishra, P. Mayank and A. Tiwari (2016).Persistence and structure of the fish assemblage from the Ganga river (Kanpur to Varanasi section), India. J.Geogr. and Nat. Dis., 6: 159 . Doi: 10.4172/21670587.1000159.

Dwivedi, A.C., N.P. Tewari and K.R. Singh (2004). Present structure of capture and culture fishery of the Faizabad District (U.P.). Bioved, 15(1,2): 95-98.

Gupta, R.A. and R.K. Tyagi (1992). Analytical approach to analysis of fish stock of Ganga river system.J. Inland. Fish. Soc. India,24(2): 20-27.

Jhingran, A.G. and K.K. Ghosh (1978).The fisheries of the Ganga river system in the context of Indian aquaculture. Aquacul., 14: 141-162.

Jhingran, V.G. (1982). Fish and Fisheries of India. Hindustan Publishing Corporation India $2^{\text {rd }}$ Edition, pp 1-727.

Katiha, P.K and R. Chandra (1990).Fish marketing efficiency. A case study of Allahabad market.Fish.Chim.,10(7): 21-28.

Katiha, P.K, R. Chandra, R.K. Tyagi and P.N. Jaitly (1998).The exploitation of riverine fish stock in temporal context. In: Fish Genetic and Biodiversity Conservation, pp 39-46, A.G. Ponniah, P. Das and S.R. Verma (Eds.), NACTON Spl. Publn. 5, Nature Conservation, Muzaffarnagar.

Kumar, D. (1996). Fishery of river Ganga around Patna and its conservation.J. Inland Fish. Soc. India, 28(2): 13-19.

Kurein, J. and S.S. Mathew (1982).Technological change in fisheries. Its impact on fishermen. Centre for Development Studies, Trivandrum.

Masud, S. (2004). Status of fish markets in Jammu. Fish.Chim.,24(6): 27-28.

Mayank, P. and A. C. Dwivedi (2015). Biology of Cirrhinus mrigala and Oreochromis niloticus. LAP LAMBERT Academic Publishing GmbH \& Co. KG, DudweilerLandstr. 99, 66123 Saarbrucken, Germany, pp. 188.

Mayank, P., A. C. Dwivedi and R. K. Pathak (2018). Age, growth and age pyramid of exotic fish species Oreochromis niloticus (Linnaeus 1758) from the lower stretch of the Yamuna river, India. Natn Acad. Sci. Lettr, 41(6): 345-348. DOI: org/10.1007/s-40009018-0673-7.

Mishra, D.N. and U. Moza (2001).Evaluation of fish and fishery resources in river Yamuna part-1.J. Inland Fish Soc. India, 33(1): 93-99.

Nautiyal P, J P Bhatt, V S Rawat \& B Kishor 2005. Fisheries ecology and bioconservation of Garhwal Himalayan Mahseer p 143-160. In Nautiyal P, Bhatt J P, Gusain O P \& Dobriyal A K (eds.) 
Biological Diversity in Freshwater Environments Transmedia, Srinagar,

Nautiyal, P., R. Nautiyal, V. P. Semwal, A. S. Mishra, J. Verma, D. P. Uniyal, M. Uniyal and K. R. Singh (2013). Ecosystem health indicators in the Ganga basin (Uttarakhand, India): Biodiversity, spatial patterns in structure and distribution of benthic diatoms, macro-invertebrates and ichthyofauna. Aquat. Ecosyst. Health Mgmt , 16(4): 362-373.

Pathak, R. K., A. Gopesh and A. C. Dwivedi (2011).Alien fish species, Cyprinus carpio var. communis (common carp) as a powerful invader in the Yamuna river at Allahabad, India. Natn Acad. Sci. Lettr., 34 (9 \& 10): 367-373.

Pinder, A. C., J. R. Britton, A. J. Harrison, P. Nautiyal, S. D. Bower, S. J. Cooke, S. Lockett, M. Everard, U. Katwate, K. Ranjeet, S. W.J. Danylchuk, N. Dahanukar and R. Raghvan (2019). Mahseer (Tor spp.) fishes of the world: status, challenges and opportunities for conservation. Rev. Fish. Biol. Fisheries, doi.org/10.1007/s11160-01909566-y.

Pullin, S. (2002).Conservation Biology.The Press Syndicate of the University of Cambridge.

Rounseefell, G.A. and W.H. Everhart (1985).Fishery Science, Its Methods and Applications. International Books and Periodicals supply Service, New Delhi, pp 1444.

Salim, S. and B.K. Halawai (2005). Capture and culture fisheries of India, impact of sanitary and phytosanitary measures-in relation to exports. Fish.Chim.,24(12): 24-27.

Seth, R.N. (1996). Fisheries ecology and breeding behaviour of a catfish Aorichthys seenghala (Sykes) with special reference to its management strategies. D. Phil. Thesis submitted in the University of Allahabad, Allahabad.

Seth, R.N. and P.K. Katiha (2001). The riverine fisheries of large sized siluroids with special reference to Aorichthys seenghala (Sykes). J. Indian Fish. Assoc., 28: 1-9.
Seth, R.N. and R.S. Panwar (2001). Changing scenario of riverine fisheries of river Ganga around Allahabad.Fish.Chim.,21(7): 53-54.

Singh, H.R., A.I. Payne, S.K. Pandey and P.R. Singh (1998). Time scale changes in the catch structure of fishery in Allahabad. Proc. Nat. Acad. Sci. India,68B: 15-21.

Sisodia, R.S. (2001). Fisheries statistics and marketing in India. Appl. Fish. \&Aquac.,1(1): 163-164.

Sultan, S. (2005). Fishery sector: Achievements and opportunities in Uttar Pradesh. Fish.Chim.,24(10): 74-80.

Tiwari, A., A. C. Dwivedi and P.Mayank (2016). Time scale changes in the water quality of the Ganga River, India and estimation of suitability for exotic and hardy fishes. Hydrol Curr Res,7(3): 254. doi:10.4172/21577587.1000254.

Tripathi, S., A. Gopesh and A. C. Dwivedi (2017). Fish and fisheries in the Ganga river : current assessment of the fish community, threats and restoration. J. Exp Zool, India, 20(2): 907912.

Welcomme, R.L. (2006a). Improving the productivity of floodplains through fishery management. Internatn J. Ecol. Environ. Sci., 32(1): 15-23.

Welcomme, R.L. (2006 b). Providing for the water requirements of river fish and fisheries. Internatn J. Ecol. Environ. Sci., 32(1): 85-97.

$* * * * * * * * *$ 